\title{
Fast detection of Noroviruses using a real-time PCR assay and automated sample preparation Michael Schmid*1, Rainer Oehme ${ }^{2}$, Gunnar Schalasta1, Stefan Brockmann², Peter Kimmig ${ }^{2}$ and Gisela Enders ${ }^{1}$
}

\author{
Address: ${ }^{1}$ Institute for Virology, Infectiology and Epidemiology e.V., Rosenbergstraße 85, 70193 Stuttgart, Germany and ²Baden-Wuerttemberg \\ State Health Office, Wiederholdstraße 15, 70174 Stuttgart, Germany \\ Email: Michael Schmid* - schmid@labor-enders.de; Rainer Oehme - oehmer@lga.bwl.de; Gunnar Schalasta - schalasta@labor-enders.de; \\ Stefan Brockmann - brockmann@lga.bwl.de; Peter Kimmig - kimmig@lga.bwl.de; Gisela Enders - enders@labor-enders.de \\ * Corresponding author
}

Published: 09 June 2004

BMC Infectious Diseases 2004, 4:15
Received: 29 October 2003

Accepted: 09 June 2004

This article is available from: http://www.biomedcentral.com/147I-2334/4/15

(C) 2004 Schmid et al; licensee BioMed Central Ltd. This is an Open Access article: verbatim copying and redistribution of this article are permitted in all media for any purpose, provided this notice is preserved along with the article's original URL.

\begin{abstract}
Background: Noroviruses (NoV) have become one of the most commonly reported causative agents of large outbreaks of non-bacterial acute gastroenteritis worldwide as well as sporadic gastroenteritis in the community. Currently, reverse transcriptase polymerase chain reaction (RT$\mathrm{PCR}$ ) assays have been implemented in NoV diagnosis, but improvements that simplify and standardize sample preparation, amplification, and detection will be further needed. The combination of automated sample preparation and real-time PCR offers such refinements.
\end{abstract}

Methods: We have designed a new real-time RT-PCR assay on the LightCycler (LC) with SYBR Green detection and melting curve analysis $\left(T_{m}\right)$ to detect NoV RNA in patient stool samples. The performance of the real-time PCR assay was compared with that obtained in parallel with a commercially available enzyme immunoassay (ELISA) for antigen detection by testing a panel of 52 stool samples. Additionally, in a collaborative study with the Baden-Wuerttemberg State Health office, Stuttgart (Germany) the real-time PCR results were blindly assessed using a previously wellestablished nested PCR (nPCR) as the reference method, since PCR-based techniques are now considered as the "gold standard" for NoV detection in stool specimens.

Results: Analysis of 52 clinical stool samples by real-time PCR yielded results that were consistent with reference nPCR results, while marked differences between the two PCR-based methods and antigen ELISA were observed. Our results indicate that PCR-based procedures are more sensitive and specific than antigen ELISA for detecting NoV in stool specimens.

Conclusions: The combination of automated sample preparation and real-time PCR provided reliable diagnostic results in less time than conventional RT-PCR assays. These benefits make it a valuable tool for routine laboratory practice especially in terms of rapid and appropriate outbreakcontrol measures in health-care facilities and other settings.

\section{Background}

NoV, members of the family Caliciviridae, are singlestranded RNA, nonenveloped viruses. Based on antigenic and genetic distinctions NoV (formerly called Norwalklike viruses) can be divided in 5 different genogroups [1]. Since the first identification of this pathogen in 1972 [2], 
NoV have become one of the most commonly reported causative agents of large outbreaks of non-bacterial gastroenteritis worldwide as well as sporadic gastroenteritis in the community [3-6]. NoV usually cause acute self-limited infections in humans of all ages. However, NoV infection can be severe in frail elderly persons, young children, and immunocompromised persons and medical attention may be required to prevent dehydration and nosocomial spread. After an incubation period of 1 to 3 days, the clinical manifestations are characterized by diarrhoea that lasts 12 to 60 hours and is frequently accompanied by a variety of other symptoms such as nausea, vomiting, and abdominal cramps. Headache and low-grade fever are also commonly reported with $\mathrm{NoV}$ illness (reviewed in [7]). Viral spread from person-to-person via the faecaloral route or through vomiting is the major mode [8], but also the importance of food and water in disease transmission is well-recognized [9-11].

Initially, direct and immune electron microscopy (EM) were used to detect the presence of NoV in fecal specimens, however EM diagnosis has a low sensitivity and is dependent upon collection of samples 2-3 days after the onset of illness. Moreover, EM is not routinely implemented in the laboratory because of technical limitations and dependency on trained medical staff for its operation.

With the breakthrough in cloning and sequencing of $\mathrm{NoV}$ genome, antigen detection assays based on baculovirusexpressed NoV capsid antigens have been developed (reviewed in [12]). These assays are type-specific, however they are not broadly reactive. Subsequently, RT-PCR assays have become the method of choice both due to their unsurpassed sensitivity and the ability to detect genetically diverse NoV strains [13-20]. Today, there is keen interest for standardization and automation for molecular tests.

The combination of automated sample preparation using the MagNA Pure extraction robot and the LightCycler PCR system (both Roche Applied Science, Mannheim, Germany) now provides such a standardized application format. Unlike the classic RT-PCR techniques, the closed format of real-time PCR avoids carryover contaminations with amplified products. As a result of reduced cycle times and lack of post-amplification processing steps, the turnaround time of the assay is considerably shorter and test results can be generated in a timely manner.

Here, we describe the application of a SYBR Green based real-time PCR assay to directly detect the presence of $\mathrm{NoV}$ RNA in stool specimens using the LC instrument. The results of the new assay were evaluated against antigen ELISA and nPCR results. The objectives of this study were to determine the test characteristics such as reliability and reproducibility, as well as to assess the clinical value of the new assay. A particular goal was to combine a real-time PCR-based approach with an automated sample preparation system, which is especially beneficial for clinical laboratories handling large numbers of specimens.

\section{Methods \\ Samples}

A total of 52 routine diagnostic samples from different patients were used in this study. The samples were collected from January 2003 through April 2003. Although we have collected the samples within a short period of time, the samples originate from various geographical areas in Germany. Of the 52 samples, 38 were obtained from patients implicated in several outbreaks of supposed gastroenteritis in different settings, including nursing and residential homes, and hospitals. Unfortunately, only data of age and gender are available $(13.1 \%$ were less than 10 years of age, $39.5 \%$ between 10 and 60 years, and $47.4 \%$ more than 60 years old). The remaining 14 samples were cases of single sporadic gastroenteritis obtained from children $<5$ years of age, which have been already tested for rotavirus and adenovirus by antigen ELISA. These patients presented clinical symptoms of acute diarrhoea (loose or watery stools, diarrhoea with vomiting, nausea, and associated symptoms including fever or signs of dehydration).

Fecal specimens were collected each in sterile containers and immediately processed upon receipt for real-time PCR and antigen ELISA and stored at $-20^{\circ} \mathrm{C}$ until further processing by nPCR.

\section{Sample processing}

For real-time PCR testing, a 10\% (wt/vol) stool suspension was prepared in $500 \mu \mathrm{l}$ PCR-grade water, and centrifuged at $16.000 \times \mathrm{g}$ for $5 \mathrm{~min}$ at room temperature. $200 \mu \mathrm{l}$ of the clarified supernatant was used for extraction of RNA on the MagNA Pure instrument.

\section{Automated nucleic acid isolation}

Viral RNA preparation was performed on the automated MagNA Pure instrument by using the MagNA Pure total nucleic acid isolation kit (Roche Applied Science, Mannheim, Germany). The MagNA Pure is a benchtop instrument that can extract nucleic acids from 32 samples in parallel. The instrument software guides the user through the set up procedure and automatically calculates the amount of reagents needed for processing. All remaining pipetting steps of the procedure were automatically performed with aerosol-preventive, disposable reaction tips. After incubation with a chaotropic lysis buffer and proteinase $\mathrm{K}$, nucleic acids were released and bound to magnetic glass particles. Unbound molecules are removed by 
Table I: Summary of NoV primers used

\begin{tabular}{|c|c|c|c|}
\hline \multicolumn{4}{|c|}{ Real-time PCR (polymerase gene) } \\
\hline Primer & Location & Oligonucleotide sequence ( $5^{\prime}$ - $\left.3^{\prime}\right)$ & Reference \\
\hline NVplloa & $4865-4883$ & ACDATYTCATCATCACCATA & 18 \\
\hline$N V p 36^{a}$ & $4487-4505$ & ATAAAAGTTGGCATGAACA & 15 \\
\hline NV NIb & $4495-4515$ & GAATTCCATCGCCCACTGGCT & 17 \\
\hline \multicolumn{4}{|c|}{ Nested PCR (polymerase gene) } \\
\hline Primer & Location & Oligonucleotide sequence (5' - 3') & Reference \\
\hline Primer $32^{b}$ & $4226-4245$ & ATGAATATGAATGAAGATGG & 23 \\
\hline Primer $36^{a}$ & $4980-4961$ & ATTGGTCCTTCTGTTTTGTC & 23 \\
\hline Primer $35^{a}$ & $4890-4871$ & GTTGACACAATCTCATCATC & 23 \\
\hline Primer $33^{b}$ & $4280-4299$ & TACCACTATGATGCAGATTA & 23 \\
\hline
\end{tabular}

Annealing site refer to a GenBank accession no. M8766I and bGenBank no X86557

several washing steps and RNA eluted in $60 \mu \mathrm{l}$ elution buffer. Purified RNA was stored at $-20^{\circ} \mathrm{C}$.

\section{Primer}

Primer sets from previously published assays which amplify a conserved region within the RNA-dependent RNA polymerase gene were used. Sequences were compared against those listed in GenBank by using the basic local alignment search tool (BLAST) to ensure a high level of specificity against NoV. Oligonucleotide primers used in this study are listed in Table 1.

\section{Real-time PCR}

Real-time PCR was done using the LightCycler system with SYBR Green detection and $\mathrm{T}_{\mathrm{m}}$ analysis. QuantiTect ${ }^{\mathrm{TM}}$ SYBR $^{\circledast}$ Green RT-PCR kit was purchased from Qiagen, (Qiagen, Hilden, Germany). Amplification is performed in a total volume of $20 \mu \mathrm{l}$ containing $10 \mu \mathrm{l}$ of kit-supplied QuantiTect $^{\mathrm{TM}}$ SYBR $^{\circledast}$ Green RT-PCR Master mix (including HotStar Taq DNA polymerase, reaction buffer, dNTP mix, and SYBR dye), $0.5 \mu \mathrm{M}$ of each primer, $1 \mu \mathrm{l}$ RNase-free water, $0.2 \mu$ l kit-supplied QuantiTect RT mix (reverse transcriptase), and $6.8 \mu \mathrm{l}$ of probe. Prior to cycling, the glass capillaries are sealed, placed into the LC sample carousel, and centrifuged at $700 \times \mathrm{g}$ for $5 \mathrm{~s}$ in the LC carousel centrifuge (Roche). Amplification conditions consisted of four consecutive phases: (i) a reverse transcription step $\left(50^{\circ} \mathrm{C}\right.$ for $\left.20 \mathrm{~min}\right)$, (ii) an initial denaturation step in order to activate the HotStarTaq DNA Polymerase $\left(95^{\circ} \mathrm{C}\right.$ for $15 \mathrm{~min}$ ), (iii) a touch-down profile for 10 cycles $\left(94^{\circ} \mathrm{C}\right.$ for $5 \mathrm{sec}, 65^{\circ} \mathrm{C}$ for $15 \mathrm{sec}$ and $72^{\circ} \mathrm{C}$ for $25 \mathrm{sec}$ ) with a $1^{\circ} \mathrm{C}$ step size temperature ramp per cycle from $65^{\circ} \mathrm{C}$ to $55^{\circ}$, (iv) an amplification step for 26 cycles $\left(94^{\circ} \mathrm{C}\right.$ for $15 \mathrm{sec}$, $55^{\circ} \mathrm{C}$ for $15 \mathrm{sec}$, and $72^{\circ} \mathrm{C}$ for $25 \mathrm{sec}$ ). To identify PCR products generated in the presence of SYBR Green, a $T_{m}$ analysis is performed by increasing the temperature from $60^{\circ} \mathrm{C}$ to $90^{\circ} \mathrm{C}$ at a linear transition rate of $0.1^{\circ} \mathrm{C} / \mathrm{sec}$. Fluorescence of the samples is monitored continuously while the temperature is increased. SYBR Green is released upon denaturation, which results in a decreasing fluorescence of the signal. The LC software calculates the $\mathrm{T}_{\mathrm{m}}$, i.e. the rate of change in fluorescence $(-\mathrm{dF} / \mathrm{dT})$ is displayed as a function of temperature. All samples were analyzed once. Recommended optimisation by titration of appropriate primer concentrations was performed.

\section{Controls}

To monitor crossover contaminations $200 \mu \mathrm{l}$ of PCRgrade water was included in the RNA extraction procedure and used as a negative control. To ensure quality and reproducibility of data, both a low-run control (i.e. purified NoV RNA) and a negative control were always applied in each run. In order to prevent PCR carryover contamination extraction of nucleic acids and amplification were performed in different rooms. Barrier-filtered pipette were used in all manipulations with the samples.

\section{Interpretation}

A sample was only considered positive if both the sample quantification curve became exponential, and the PCR product was correctly differentiated by the $\mathrm{T}_{\mathrm{m}}$ analysis step.

\section{NoV detection by nested RT-PCR}

NoV RNA was extracted from coded patients's specimens using a method based on the lysing and nuclease-inactivating properties of guanidinium thiocyanate with the nucleic acid-binding properties of silica particles [21]. A $20 \%$ (wt/vol) stool suspension was prepared in $1 \mathrm{ml}$ PCRgrade water, vortexed, and centrifuged at $16.000 \times \mathrm{g}$ for 3 min. Reaction vessels were prepared with $900 \mu \mathrm{l}$ lysis buffer (5.25 M GuSCN, 50 mM Tris HCl, pH 6.4, 20 mM 
EDTA, 1.3\% wt/vol Triton X-100) and $40 \mu \mathrm{l}$ of silica matrix to a $2 \mathrm{ml}$ Eppendorf reaction tube. $300 \mu \mathrm{l}$ of the clarified supernatant was added to the reaction vessels, and immediately vortexed. After $10 \mathrm{~min}$ at room temperature, the vessel was vortexed again and centrifuged at $16.000 \times \mathrm{g}$ for $15 \mathrm{~s}$. The supernatant was disposed of by suction. The silica pellet was subsequently washed twice with $1 \mathrm{ml}$ washing buffer (5.25 M GuSCN, $50 \mathrm{mM}$ Tris $\mathrm{HCl}, \mathrm{pH} 6.4$ ), twice with $1 \mathrm{ml}$ ethanol $70 \%$ (vol/vol), and once with $1 \mathrm{ml}$ acetone. After centrifugation (3 min at approximately $16.000 \times \mathrm{g}$ ), the supernatant was disposed of by suction. The vessels were dried at $56^{\circ} \mathrm{C}$ with open lids in a heat block for $10 \mathrm{~min}$. For elution, $75 \mu \mathrm{l}$ nuclease free water and $1 \mu \mathrm{l}$ rRNasin (Promega, Mannheim, Germany) were added, and the closed vessel was vortexed briefly, and incubated for $10 \mathrm{~min}$ at $56^{\circ} \mathrm{C}$. The vessel was vortexed again and centrifuged for $3 \mathrm{~min}$ at $16.000 \times \mathrm{g}$. For reverse transcription (RT) $5 \mu \mathrm{l}$ of the DNA and RNA containing supernatant was used. RT was carried out with the AMV-RT (Roche Applied Science, Mannheim, Germany) and the antisense primer 36. RT was performed for one cycle $\left(25^{\circ} \mathrm{C}, 10 \mathrm{~min} ; 42^{\circ} \mathrm{C}, 60 \mathrm{~min} ; 98^{\circ} \mathrm{C}, 5 \mathrm{~min}\right)$. Part of the cDNA was amplified by nested PCR using primer 32 and primer 36 for the first round, and primer 33 and primer 35 for the second round. Amplifications were performed for 35 cycles $\left(94^{\circ} \mathrm{C}, 30 \mathrm{~s} ; 42^{\circ} \mathrm{C}, 30 \mathrm{~s}\right.$; $\left.72^{\circ} \mathrm{C}, 45 \mathrm{~s}\right)$. The cycles were proceeded by a $1 \mathrm{~min}$ denaturation and followed by a 3 min extension at $72^{\circ} \mathrm{C}$. PCR products were visualized on agarose gels after electrophoresis coupled with ethidium bromide staining and viewed on a UV transilluminator. Nested PCR was performed in a second laboratory without knowledge of LCPCR test results. The sensitivity of the nPCR using serial dilutions of spiked clinical specimens was comparable to real-time PCR analysis. Primer sequence and nested RTPCR set up have been previously described [22].

\section{NoV detection by antigen ELISA}

The RIDASCREEN ${ }^{\circledR}$ Norwalk-like Virus kit was purchased from R-Biopharm (R-Biopharm, Darmstadt, Germany) and used for the detection of Norwalk-like viruses (NLVs) of the genogroup I and II in stool specimens. This enzyme immunoassay is based on monoclonal antibodies bound on the surface of the microwell strips to capture the antigen in stool specimens. All reagents were kit-supplied. For sample preparation, stool samples were diluted 1:6 (v/v) in the diluent buffer, mixed thoroughly, allowed 5-10 min to settle, and further processed according to the protocol recommended by the manufacturer. Briefly, $100 \mu \mathrm{l}$ supernatant of the prepared stool suspension are transferred into separate wells and incubated at room temperature for $60 \mathrm{~min}$. After complete removing of the liquid, the wells are washed 5 times with $300 \mu$ l wash buffer. Two drops of enzyme conjugate are added to each well, incubated at room temperature for $30 \mathrm{~min}$. After 5 times wash- ing (see above), the bound conjugate was determined by the addition of a chromogen and enzyme substrate. The absorbance is measured at $450 \mathrm{~nm}$. The kit cut-off used is determined by addition of 0.15 absorbance units to the measured absorption $(450 \mathrm{~nm})$ of the negative control.

\section{Statistical analysis}

Comparisons involving $\mathrm{C}_{t}$ values of PCR-positive ELISApositive and PCR-positive but ELISA-negative samples were analysed by the Mann-Whitney U test using statistical software SPSS, version 11.5.1 (SPSS inc., Chicago, USA). For comparison of proportion the chi square test was used.

\section{Results \\ Optimization strategies}

Real-time PCR affords continuous monitoring of the PCR reaction cycle by cycle by using fluorescence. The detection in our assay is based on the binding of the fluorescent dye SYBR Green, which binds all double stranded DNA molecules. Since this process is sequence independent, the characteristic $\mathrm{T}_{\mathrm{m}}$ of the target is determined by performing a melting curve analysis on the PCR products. To reduce the formation of primer-dimers and non-specific products, which compete with formation of specific PCR products, leading to reduced amplification efficiency, we include a touch-down step in the thermal cycling program. By using restricted annealing temperature, formation of unexpected double-stranded DNA products and primer-dimers were not observed (Fig. 1). In addition, both purity and concentration of primers are essential for optimal working conditions.

\section{Detection range, sensitivity, specificity, reproducibility}

To validate the real-time assay prior to application, we determined the detection range using tenfold serial dilutions of a patient's stool sample. The assay was able to detect NoV RNA within a range of up to 5 logs. The resulting curve with a slope of -3.251 , and a coefficient of correlation $r=-0.99$ indicates a high efficiency of RT-PCR and a strong linear relationship (results not shown). $\mathrm{T}_{\mathrm{m}}$ analysis of the PCR product revealed a distinct temperature at which the double stranded amplicon is denatured (mean $\mathrm{T}_{\mathrm{m}} 78.9^{\circ} \mathrm{C}$; range 78.2 to 81.2 ). No increase in fluorescence signal from primer-dimers or other non-specific amplification products (distinguished from the specific product through their lower $\mathrm{T}_{\mathrm{m}}$ ) was monitored (Fig. 1). To assess specificity, we tested the assay with RNA or DNA (high run controls as templates) from several viral pathogens usually associated with gastroenteritis diseases. No cross-amplification was observed when a panel of enteric viruses, including hepatitis A, hepatitis E, enterovirus, rotavirus and adenovirus, was tested as described above for NoV (results not shown). Reproducibility of the assay was evaluated by measuring the threshold cycle $\left(C_{t}\right)$, i.e. 


\section{Melting curve analysis}

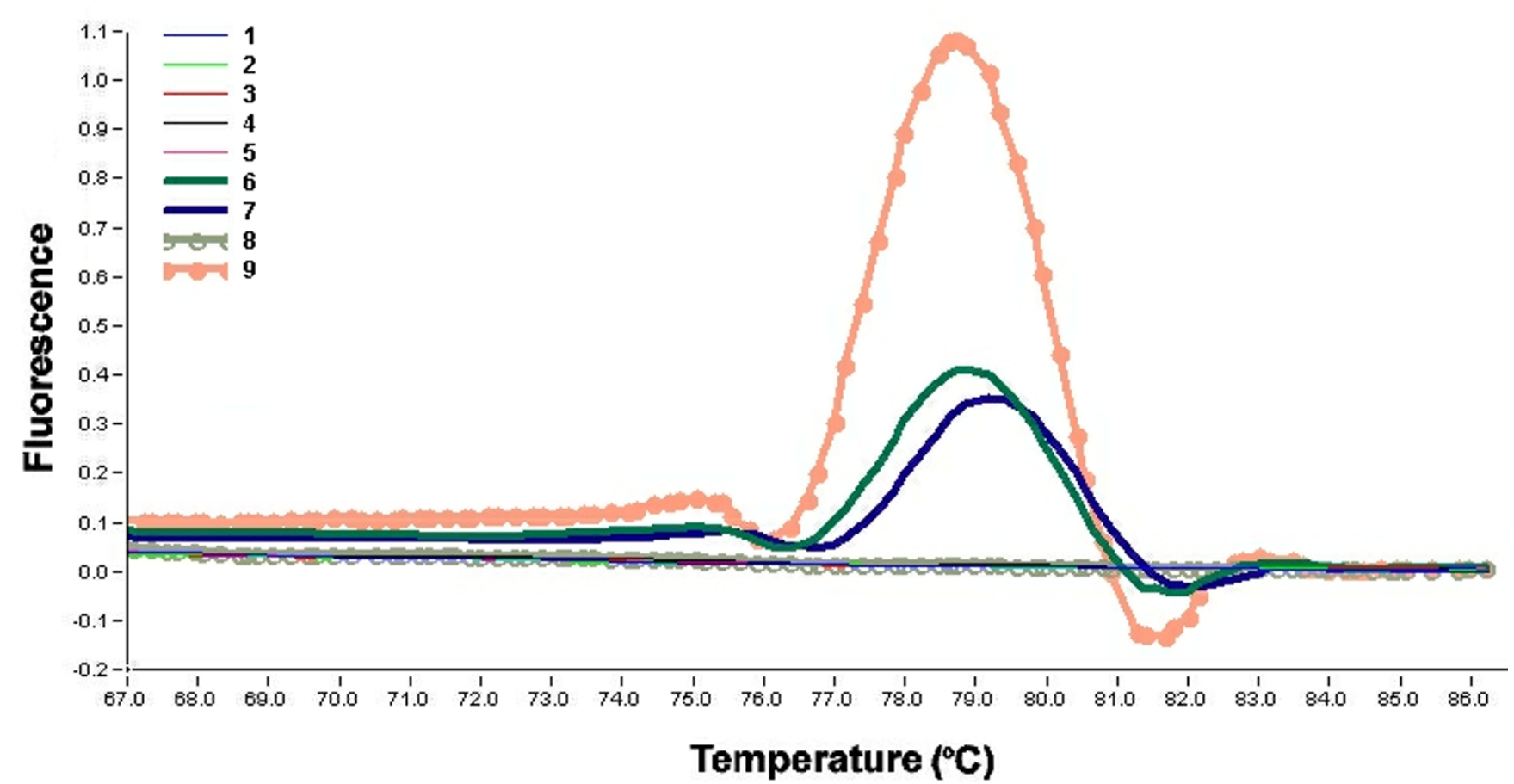

\section{Figure I}

$T_{m}$ analysis of real-time PCR with SYBR Green as fluorescent dye. $T_{m}$ analysis allows the differentiation of specific PCR product (amplicon) from non-specific amplification products, such as primer-dimers. Samples: I to 7, patient samples (stool); 8, negative control (water); 9, positive control (NoV positive stool). Amplified products from NoV template RNA can be reliably distinguished from non-specific products by different melting points. The melting temperature for the positive samples was $79.0+/-$ $0.5^{\circ} \mathrm{C}$. Non-specific products melt at lower temperatures.

the cycle with the first detectable increase in fluorescence, of a low run control on three consecutive days six times. To determine the intra-assay precision, three stool specimen were simultaneously tested three times. The assay showed a between-run coefficient of variation (CV) of $<3 \%$, while the within-run coefficient was $<2 \%$, indicating that the assay was efficiently reproducible.

\section{Comparison of results obtained by real-time $P C R$, antigen ELISA, and $n P C R$}

Results of real-time PCR were compared with those of antigen ELISA and reference nPCR. We found a 100\% correlation between the results of real-time PCR and those obtained by nPCR. By antigen ELISA 18 of 52 (34.6\%) samples were positive for $\mathrm{NoV}$, whereas both real-time PCR and nPCR detected 26 (50\%), respectively. Of the antigen ELISA-positive samples, only 50\% (9/18) were confirmed by the two PCR-based methods. In contrast, real-time PCR and nPCR detected 17 samples that were not identified by antigen ELISA. An identical result in all three tests was obtained in 50\% (26/52) of the samples. Seventeen specimens were negative by all tests. The mean $C_{t}$ value for real-time PCR was 28.9 [95\% confidence interval (CI), 27.3 to 30.5 ; range 18.5 to 34 ] and the mean $\mathrm{T}_{\mathrm{m}}$ was $78.9^{\circ} \mathrm{C}(95 \% \mathrm{CI} 78.7$ to 79.1 ; range 78.2 to 81.2$)$. All our negative controls showed no fluorescence signal. The mean optical density (OD) value for antigen ELISA was 1.0 (95\% CI 0.5 to 1.5 ; range 0.2 to 3.6 ). Table 2 shows the combined results of antigen ELISA, real-time PCR, and nPCR for the total of 52 specimens.

Table 2: Pattern of NoV test results for 52 stool specimens

\begin{tabular}{|c|c|c|c|}
\hline Elisa & $\begin{array}{c}\text { Results of: } \\
\text { Real-time PCR }\end{array}$ & $\mathrm{nPCR}$ & No. of specimens $(N=52)$ \\
\hline+ & + & + & 9 \\
\hline- & + & + & 17 \\
\hline+ & - & - & 9 \\
\hline- & - & - & 17 \\
\hline
\end{tabular}


Table 3: Comparison of real-time PCR and Elisa test performance to $\mathrm{nPCR}$

\begin{tabular}{lcc}
\hline Laboratory Test & $\begin{array}{c}\text { No. of specimens with test result/no. specimens } \\
\text { with result by nPCR as reference (\%) }\end{array}$ \\
\hline & Sensitivity & Specificity \\
\hline Elisa & $9 / 26(34.6)$ & $17 / 26(65.3)$ \\
Real-time PCR & $26 / 26(100)$ & $26 / 26(100)$
\end{tabular}

\section{Relative sensitivity}

The choice of a reference test is crucial for evaluation of any new assay. In order to ensure specificity of the new real-time PCR assay, we tested all samples by an additional confirmatory assay (nPCR) in a blinded fashion. Comparison of real-time PCR and nPCR as a reference test in 52 clinical specimens resulted in an excellent agreement. Conversely, the results of reference nPCR and antigen ELISA disagreed. The clinical performance of antigen ELISA and real-time PCR after additional testing by nPCR are listed in Table 3.

\section{Viral loads}

To explain the substantial difference of the results by realtime PCR and antigen ELISA, we compared the viral load of PCR-positive ELISA-positive specimens with those of PCR-positive but ELISA-negative specimens. This comparison is based on the assumption that high $\mathrm{C}_{\mathrm{t}}$ values are representative of low viral load, whereas low $C_{t}$ values are representative for high viral load. The mean $C_{t}$ values obtained by real-time PCR for ELISA-positive and ELISAnegative samples were 31.2 (range 26.7 to 34 ) and 27.7 (range 18.5 to 34 ), respectively. Statistical significance between the mean $\mathrm{C}_{\mathrm{t}}$ values of ELISA-positive and ELISAnegative samples was tested by the Mann-Whitney $U$ test $(p=0.039)$. The actually higher $C_{t}$ values of ELISA-positive samples indicate that NoV RNA was even present at lower levels in these samples. On the basis of this finding, the failure to detect virus antigen in some real-time PCR positive samples cannot be explained by low virus titer in the samples.

\section{Discussion}

It is generally assumed that ELISA antigen techniques are less sensitive than PCR-based assays and therefore we choose the latter as the routine diagnostic assay for detection of NoV RNA in patient specimens. To validate the performance of our new real-time assay we collaborated with another diagnostic laboratory performing nPCR analysis for NoV detection. This approach ensures that primer annealing temperatures are stringent enough and that $T_{m}$ analysis reliably distinguishes the specific PCR products and possible PCR by-products. We consider nPCR as a reliable test that can be used as a reference method for the following reasons: (i) the efficiency of the nPCR has been previously shown to work well in outbreak investigations [22-24], and (ii) the NPCR primer set has been proven recently in an international collaborative study [25], adding further confidence to the specificity of the reference test used.

All real-time PCR-positive results were confirmed by nPCR. This congruence offers a firm background for the clinical utility and performance of the new real-time assay. Furthermore, compared to the nPCR protocol, the routine work flow reduced hands on-time and the turnaround time to the final result allowed same-day reporting to the clinician.

Consistent with previous studies [26,27], we found antigen ELISA to be significantly less sensitive than real-time PCR $(34.6 \%$ vs. $100 \% ; \mathrm{P}<0.001 \%)$. We regard the positive results by real-time PCR as reliable on the strength of following reasons. First, the combined use of a stringent hot start PCR and touch-down cycling conditions reduces the formation of non-specific amplification products and primer-dimers. Second, the characteristic $\mathrm{T}_{\mathrm{m}}$ of the target was determined by melting curve analysis to prevent false-positive results. Third, and most important, all results were corroborated by the reference nPCR. By use of these compelling criteria, it can be considered that false-positive results are unlikely.

Different sample volume analyzed could account for the differing results. To proof this, we compared the viral load of PCR-positive ELISA-positive specimens with those of PCR-positive but ELISA-negative samples. The first cycle at which the fluorescence passes from background levels to clearly detectable is called the threshold cycle $(\mathrm{Ct})$. This value serves as a tool for calculating semiquantitatively the amount of starting template in the clinical sample, i.e. the higher the $\mathrm{C}_{\mathrm{t}^{\prime}}$ the lower the amount of starting templates. Surprisingly, the mean $C_{t}$ values were significantly higher in PCR-positive ELISA-positive samples, indicating the presence of even lower levels of viral RNA. In this regard, it is particularly relevant that in stool NoV antigens are present in higher concentrations than intact virus particles [28] suggesting that stool antigen concentrations could not have affected the performance of antigen ELISA. Although, the $\mathrm{C}_{t}$ values depend greatly on the homology of primer and target sequences, it is unlikely that the results are biased by a special NoV genotype, since the samples originate from different geographical regions in Germany. Sequence determination of these strains was not done. Alternatively, the failure to detect viral antigen in some of the real-time PCR positive samples could be due to the wide genetic diversity of NoV. Although anti- 
gen ELISA are broadly reactive, the monoclonal antibodies used in the test may detect only antigenically similar or the most closely related NoV strains.

Only 9 of 18 ELISA-positive results could be confirmed by real-time PCR and nPCR, respectively, Factors that may adversely affect the sensitivity of the amplification assays include inefficient RNA extraction procedure, PCR inhibitors in faecal samples, and RNA degradation before testing. To rule out PCR inhibitors, we spiked all 9 ELISA-only positive samples with a NoV low-run control, but no PCR inhibitiors were detected.

Other reasons for the inability to detect NoV RNA could be low level of intact viral particles, or sequence variation (e.g., mismatches at critical positions in the primer binding site) in the viral RNA polymerase region. This is consistent with previous reports of genomic diversity of $\mathrm{NoV}$ strains even in the conserved region of open reading frame 1 (ORF1) coding for the viral RNA polymerase $[29,30]$. To rule out that we have missed these strains due to genetic variability, we have tested in addition all nine ELISA-only positive samples with a PCR-protocol using the primer pair JV12-JV13 targeting the RNA-dependent RNA polymerase gene [25]. All 9 ELISA-only positive samples were also negative by using this protocol. Thus, it is very unlikely that the negative result by real-time PCR was related to genetic variability.

On the other hand, false positive results of the antigen ELISA cannot be excluded. Two of the nine ELISA-onlypositive samples had OD values that were in the equivocal range of the assay, i.e. marginally above the cut-off level of the test. These results were not resolved upon retesting. Notably, three of the samples with the high OD values of 2.5, 3.3, and 3.6 in the antigen ELISA were negative by real-time PCR.

Clearly the design of primer and probes capable for detecting a broad range of NoV strains is an ongoing challenge given the genetic diversity of the NoV genus. Recently, a real-time RT-PCR assay was established with sequence-specific probes for detection of NoV [31]. The use of SYBR Green offers the advantage of real-time detection even in the case of template sequence variation, which may abolish detection using hybridization probes.

There are two limitations to this study: (i) no internal control is added to the specimens prior to nucleic acid extraction as provided in part by commercially developed assays, and (ii) since our assay is based on SYBR Green, the assay cannot distinguish between NoV of GI and GII.

In conclusion, we describe a real-time PCR assay which detects the presence of NoV RNA in stool samples. The new assay provides accurate diagnostic results in less time than currently employed conventional PCR-assays. The automated sample preparation offers high throughput without cross-contamination of specimens during processing as well as standardization of operation steps. There is a keen interest in rapid and reliable assay in clinical situations to contain the spread of the virus in hospitals or other settings such as geriatric care facilities.

\section{Competing interests}

None declared.

\section{Authors' contributions}

MS conceived and designed the study, carried out the assay development, data analysis, and wrote first draft of manuscript. RO carried out nPCR analysis, participated in the design of the study and critical review of the manuscript. GS conceived and designed the study and participated in the writing of the manuscript. SB performed antigen ELISA testing and critically reviewed the manuscript. PK provided expert input for writing. GE provided expert input for writing and supervised the study. All authors have read and approved the final manuscript.

\section{Acknowledgements}

We thank Susan Kunze and Sabine Meier for expert technical assistance, Tessa Lachmund for assistance with statistical analysis.

\section{References}

I. Ando T, Noel JS, Frankhauser RL: Genetic classification of "Norwalk-like viruses". J Infect Dis 2000, I 8 I 2(Suppl 2):S336-S348.

2. Kapikian AZ, Wyatt RG, Dolin R, Thornhill TS, Kalica AR, Chanock RM: Visualization by immune electron microscopy of a 27 $\mathrm{nm}$ particle associated with a non-bacterial gastroenteritis. J Virol 1972, 10:1075-1081.

3. Vinjé J, Altena SA, Koopmans MPG: The incidence and genetic variability of small round-structured viruses in outbreaks of gastroenteritis in the Netherlands. J Infect Dis 1997, I76: I 374-1378.

4. Frankhauser RL, Noel JS, Monroe SS, Ando T, Glass RI: Molecular epidemiology of ,Norwalk-like viruses" in outbreaks of gastroenteritis in "The United States. J Infect Dis 1998, I78: I57|-I578.

5. Foley B, O'Mahony J, Morgan SM, Hill C, Morgan JG: Detection of sporadic cases of Norwalk-like virus (NLV) and astrovirus infection in a single Irish hospital from 1996 to 1998. J Clin Virol 2000, I 7:109-117.

6. Lopman BA, Reacher MH, Van Duijnhoven Y, Hanon FX, Brown DWG, Koopmanns $M$ : Viral gastroenteritis outbreaks in Europe, 1 995-2000. Emerg Infect Dis 2003, 9:90-96.

7. Green KY, Chanock RM, Kapikian AZ: Human Caliciviruses. In Fields virology Volume I. 4th edition. Edited by: Knipe DM, Howley PM. Lippincott Williams \& Wilkins, Philadelphia, Pa; 200 I:84I-874.

8. Marks PJ, Vipond IB, Carlisle D, Deakin D, Fey RE: Evidence for airborne transmission of Norwalk-like virus (NLV) in a hotel restaurant. Epidemiol Infect 2000, I 24:48I-487.

9. Lees DN, Henshilwood K, Green J, Gallimore Cl, Brown DWG: Detection of small round structured viruses in shellfish by reverse transcription-PCR. Appl Environ Microbiol 1995, 6 I:4418-4424.

10. Kukkula M, Maunula L, Silvennoinen E, von Bonsdorff $\mathrm{CH}$ : Outbreak of viral gastroenteritis due to drinking water contaminated by Norwalk-like viruses. J Infect Dis 1999, I 80: I77।-I776.

I I. Daniels NA, Bergmire-Sweat DA, Schwab KJ, Hendricks KA, Reddy S, Rowe SM, Frankhauser RL, Monroe SS, Atmar RL, Glass RI, Mead P: A foodborne outbreak associated with Norwalk-like viruses: 
first molecular traceback to deli sandwiches contaminated during preparation. J Infect Dis 2000, 181:1467-1470.

12. Atmar RL, Estes MK: Diagnosis of noncultivatable gastroenteritis viruses, the human caliciviruses. Clin Microbiol Rev 200I, 14:15-37.

13. Jiang X, Wang J, Graham DY, Estes MK: Detection of Norwalk virus in stool by polymerase chain reaction. I Clin Microbiol 1992, 30:2529-2534.

14. Moe CL, Gentsch J, Ando T, Grohmann GS, Monroe SS, Jiang $X$, Wang J, Estes MK, Seto Y, Humphrey C, Stine S, Glass RI: Application of PCR to detect Norwalk virus in fecal specimens from outbreaks of gastroenteritis. / Clin Microbiol 1994, 32:642-648.

15. Wang J, Jiang X, Madore HP, Gray J, Desselberger U, Ando T, Seto Y, Oishi I, Lew JF, Green KY, Estes MK: Sequence diversity of small, round-structured viruses in the Norwalk virus group. J Virol 1994, 68:5982-5990.

16. Ando T, Monroe SS, Gentsch JR, Jin Q, Lewis DC, Glass RI: Detection and differentiation of antigenically distinct small roundstructured viruses (Norwalk-like viruses) by reverse transcription-PCR and Southern hybridisation.J Clin Microbiol 1995, 33:64-7I.

17. Green J, Gallimore CI, Norcott JP, Lewis D, Brown DWG: Broadly reactive reverse transcriptase polymerase chain reaction (RT-PCR) for the diagnosis of SRSV-associated gastroenteritis. J Med Virol 1995, 47:392-398.

18. Le Guyader F, Estes MK, Hardy ME, Neill FH, Green J, Brown DWG Atmar RL: Evaluation of a degenerate primer for the PCR detection of human caliciviruses. Arch Virol 1996, I 4I:2225-2235.

19. Schwab KJ, Estes MK, Neill FH, Atmar RL: Use of heat release and an internal RNA standard control in reverse transcriptionPCR detection of Norwalk virus from stool samples. J Clin Microbiol 1997, 35:5II-5I4.

20. Tatsumi M, Nakata S, Sakai Y, Honma S, Numata-Kinoshita K, Chiba $S$ : Detection and differentiation of Norwalk virus by reverse transcription polymerase chain reaction and enzyme-linked immunosorbent assay. I Med Virol 2002, 68:285-290.

21. Boom R, Sool CJA, Salimans MMM, Jansen CL, Wertheim van Dillen PME, van der Noordaa J: Rapid and simple method for purification of nucleic acids. J Clin Microbiol 1990, 28:495-503.

22. Fleischer J, Wagner Wiening C, Kimmig P: Verfolgung von Gruppenerkrankungen mit Norwalk-like Viren (NLV) in BadenWürttemberg. Gesundheitswesen 2000, 62:604-608.

23. Schreier E, Döring F, Künkel U: Molecular epidemiology of outbreaks of gastroenteritis associated with small round structured viruses in Germany in 1997/98. Arch Virol 2000, 1 45:443-453.

24. Brockmann S, Klittich G, Fleischer J, Oehme R, Dreweck C, Pfaff G, Kimmig P: Food- and waterborne disease outbreaks in Germany: three years experience (1999-200I) in Baden-Württemberg. Int J Med Microbiol 2002, 292: I49-150.

25. Vinjé J, Vennema $H$, Maunula L, von Bonsdorff $\mathrm{CH}$, Hoehne $\mathrm{M}$, Schreier E, Richards A, Green J, Brown D, Beard SS, Monroe SS, de Bruin E, Svensson L, Koopman MP: International collaborative study to compare reverse transcriptase PCR assays for detection and genotyping of norovirus. / Clin Microbiol 2003, 4I: I 423-I 433.

26. Richards AF, Lopman B, Gunn A, Curry A, Ellis D, Cotterill H, Ratcliffe $S$, Jenkins M, Appleton $\mathrm{H}$, Gallimore $\mathrm{Cl}$, Gray J], Brown DW: Evaluation of a commercial ELISA for detecting Norwalklike virus antigen in faeces. J Clin Virol 2003, 26:109-II5.

27. Rabenau HF, Sturmer M, Buxbaum S, Walczok A, Preiser W, Doerr HW: Laboratory diagnosis of norovirus: which method is best? Intervirology 2003, 46:232-238.

28. Graham DY, Jiang X, Tanaka T, Opekum AR, Madore HP, Estes MK: Norwalk virus infection of volunteers: new insights based on improved assays. J Infect Dis 1994, 170:34-43.

29. Green J, Norcott JP, Lewis D, Arnold C, Brown DWG: Norwalklike viruses: demonstration of genomic diversity by polymerase chain reaction. I Clin Microbiol 1993, 3 1:3007-30I2.

30. Vinjé J, Green J, Lewis DC, Gallimore Cl, Brown DWG, Koopmans MPG: Genetic polymorphism across regions of the three open reading frames of "Norwalk-like viruses". Arch Virol 2000, | 45:223-24l.

31. Kageyama T, Kojima S, Shinohara M, Uchida K, Fukushi S, Hoshino FB, Takeda N, Katayama K: Broadly reactive and highly sensitive assay for Norwal.like viruses based on real-time quantitative reverse transcription-PCR. J Clin Microbiol 2003, 41:1548-1557.

\section{Pre-publication history}

The pre-publication history for this paper can be accessed here:

http://www.biomedcentral.com/1471-2334/4/15/prepub

Publish with BioMed Central and every scientist can read your work free of charge

"BioMed Central will be the most significant development for disseminating the results of biomedical research in our lifetime. "

Sir Paul Nurse, Cancer Research UK

Your research papers will be:

- available free of charge to the entire biomedical community

- peer reviewed and published immediately upon acceptance

- cited in PubMed and archived on PubMed Central

- yours - you keep the copyright 